\title{
1. Public procurement and human rights: interrogating the role of the state as buyer
}

\author{
Olga Martin-Ortega and Claire Methven \\ O'Brien
}

\section{$1 \quad$ INTRODUCTION}

Public procurement refers to the buying by the public sector of the goods, services and works it needs to carry out its functions. ${ }^{1}$ Such purchases range widely, from infrastructure projects and the acquisition of complex weapon systems, to contracting for the provision of essential public services in the health and social care sector and the purchase of common manufactured or processed goods such as stationery, furniture, uniforms, personal electronic items and foodstuffs. Government buying comprises a significant proportion of the overall global economy. Public procurement represents 15-20 per cent of global gross domestic product (GDP), while amongst Organization for Economic Cooperation and Development (OECD) states public procurement accounts for 12 per cent GDP, on average. ${ }^{2}$ The value of commitments under the World Trade Organization (WTO) General Procurement Agreements alone is approximately EUR 1.3 trillion, worldwide. ${ }^{3}$

Governments are increasingly in the spotlight for involvement in human rights abuses via their supply chains and, as the contributions to this book illustrate, central governments, subnational and local authorities, as well as

1 Sue Arrowsmith and Peter Kunzlik, Social and Environmental Policies in EU Procurement Law: New Directives and New Directions (Cambridge University Press 2009), 9.

2 OECD, Public Procurement Website http://www.oecd.org/gov/public -procurement/. All websites in this chapter accessed 17 September 2018.

3 European Commission DG Growth, International Procurement (website) https:// ec.europa.eu/growth/single-market/public-procurement/international_en. 
international organisations, have all faced recent scandals. Via their purchasing relationships they have been linked, for instance, to forced labour, child labour, excessive working hours, unsafe working conditions and suppression of freedom of association and expression, across sectors including electronics, textiles, construction and security. ${ }^{4}$

Human rights recognise the inalienable dignity and equality of all human beings and their correlate basic entitlements. National constitutions in many if not most countries bind government bodies to honour human rights. Besides, states have international obligations to uphold human rights under treaties to which they are parties and customary international law. ${ }^{5}$ According to international human rights treaties, states must protect, respect and fulfil the human rights of persons within their jurisdiction. ${ }^{6}$ The first duty of states, to protect human rights, extends to taking reasonable steps to prevent harmful actions by third parties, including both natural and legal persons.

Taking this duty as point of departure, new international norms on responsible business and sustainability, including the United Nations Guiding Principles on Business and Human Rights (UNGPs) ${ }^{7}$ and the Guidelines for Multinational Enterprises of the $\mathrm{OECD}^{8}$ have, for the first time, explicitly addressed specific human rights responsibilities to public purchasers and the businesses that serve as their suppliers. In parallel, sustainable public consumption that respects human rights has been put in focus in the context

4 See further, International Learning Lab on Public Procurement and Human Rights (Claire Methven O'Brien et al.), Public Procurement and Human Rights: A Survey of Twenty Jurisdictions (July 2016) http://www.hrprocurementlab.org/wp -content/uploads/2016/06/Public-Procurement-and-Human-Rights-A-Survey-of -Twenty-Jurisdictions-Final.pdf.

5 Rosalyn Higgins, 'Responding to Individual Needs: Human Rights' in Rosalyn Higgins, Problems and Process (Clarendon, 1994); Theodor Meron, Human Rights and Humanitarian Norms as Customary Law (Clarendon, 1989); Olivier De Schutter, International Human Rights Law: Cases Materials, Commentary (Cambridge University Press 2014).

${ }^{6}$ Ibid, chapters 3-5. The jurisdictional limits of the duty to protect human rights in the context of business activities are discussed in Claire Methven O'Brien, 'The Home State Duty to Regulate the Human Rights Impacts of TNCs Abroad: A Rebuttal' (2018) 3 Business and Human Rights Journal, 47-73.

7 UNHRC, Guiding Principles on Business and Human Rights: Implementing the United Nations 'Protect, Respect and Remedy Framework' UN Doc. A/HRC/17/31, 21 March 2011 (hereafter UNGPs) https://www.ohchr.org/Documents/Publications/ GuidingPrinciplesBusinessHR_EN.pdf.

8 OECD, Guidelines for Multinational Enterprises http://www.oecd.org/corporate/ mne/. 
of the 2030 Agenda for Sustainable Development and related Sustainable Development Goals (SDGs). ${ }^{9}$

Yet public procurement is governed by its own distinct legal and policy frameworks. Typically, these have not referred to or explicitly recognised public buyers' human rights obligations. Rather, they have sought to advance, in the first place, the goals of lowest cost or 'value for money', even if subsidiary objectives, such as environmental efficiency, have gradually been established across a range of jurisdictions.

Hence, the public buying process can be viewed as a point of confluence for multiple normative systems and policy goals, reflecting discrete and sometimes conflicting values, but which political and social actors increasingly expect to be holistically integrated. Accordingly, our aim in this book is to explore opportunities, risks and dilemmas presented by the interface of public procurement and human rights, through a cross-disciplinary collection encompassing legal analyses (Part II) and practice-based case studies (Part III).

This introduction presents in broad contour a framework to help readers to navigate later chapters, whether they approach this topic from the disciplines of human rights, public procurement or from some other standpoint. Our first step, in Section 2, is to outline how public procurement law understands the role of the state as buyer. Section 3, by contrast, addresses this role from the vantage point of human rights law. It then highlights a wave of new norms on business, human rights, supply chains and sustainability, and briefly explains why these are now challenging conventional views about the interpretation of legal rules applicable to state purchasing. Section 4 makes the case for a revised conceptual analysis of the human rights dimension of sustainable procurement. Section 5 provides readers with a short overview of subsequent chapters.

\section{THE STATE AS BUYER: PROCUREMENT LAW PERSPECTIVES}

Public procurement, as noted, is the buying and contracting by public actors of the goods, services and works they need to fulfil their functions. ${ }^{10}$ In legal terms, procurement comprises three main phases. The first phase, procurement planning, includes deciding what goods, services and works need to be contracted; defining their technical specifications; establishing the criteria

9 UNGA, Transforming Our World: The 2030 Agenda for Sustainable Development, UN Doc. A/RES/70/1, 25 October 2015 (hereafter SDGs), Goal 12 https://sustainabledevelopment.un.org/sdg12.

10 Arrowsmith and Kunzlik (n1). 
which will be used to decide to which supplier the contract should be allocated ('award criteria'); and delineating further conditions for the delivery of the goods, services and works in question ('contract performance conditions'). The second phase is tendering and award of the contract, while the third and last comprises contract management.

Within national, supranational and international procurement law regimes, each of these phases is described by intricate rules, intended to promote the principal policy objectives of public procurement, namely: (a) the achievement of value for money ('efficiency'); (b) non-discrimination between tenderers; and (c) open competition. ${ }^{11}$

In the past, these were generally referred to as public procurement's 'primary' aims. Yet governments have often used public purchasing to promote other policy objectives, such as local or national industrial and economic development, environmental protection, or social inclusion and protection of vulnerable groups. ${ }^{12}$

Within the realm of procurement law, these have typically been labelled 'secondary' or 'complementary"13 aims of procurement, on the basis that such objectives are not necessarily connected with public buying's 'primary' functional objective of obtaining services and products at the lowest price or best 'value for money'. ${ }^{14}$ To avoid an implication of hierarchy, however, in this book we refer to such objectives as 'horizontal' rather than 'secondary' objectives. While this reflects a broader movement among procurement law scholars, ${ }^{15}$ it also aligns with our view that public buyers' human rights duties are mandatory and thus cannot be ranked within procurement law frameworks

11 Sue Arrowsmith, 'Horizontal Policies in Public Procurement: A Taxonomy' (2010) 10(2) Journal of Public Procurement, 149.

12 Christopher McCrudden, Buying social justice. Equality, government procurement and legal change (OUP 2007).

13 For example, Cantore and Togan identify the main objectives of EU procurement rules as being to 'increase the efficiency of public spending and support the attainment of the Single Market', while its complementary objectives are 'the achievement of common societal goals such as the protection of the environment, higher resource and energy efficiency, combatting climate change, promoting innovation and social inclusion, preventing and fighting corruption and favouritism, and ensuring the best conditions for the provision of high-quality public services'. In addition, its 'guiding principles' are competition, non-discrimination, transparency and objectivity: Carlo M Cantore and Sübidey Togan, 'Public Procurement in the EU' in Aris Georgopoulos, Bernard Hoekman and Petros Mavroidis (eds), The Internationalization of Government Procurement Regulation (Oxford University Press 2017), 143.

14 Arrowsmith and Kunzlik (n1), 9.

15 See Christopher McCrudden, Buying Social Justice. Equality, Government Procurement and Legal Change (Oxford University Press 2007); Arrowsmith and Kunzlik (n1) 3-54; Arrowsmith (n11); Maria Anna Corvaglia, Public Procurement 
as subordinate to price, competition or other 'primary' aims of procurement, as we discuss in Section 3 below.

Besides national public procurement regimes' complex rules, government purchases may be subject, in addition, to relevant areas of general law (for example, administrative, contract, environmental and anti-corruption laws). ${ }^{16}$ Depending on their monetary value, subject matter and obligations entered into by the state in question, they may also be governed by international rules, for instance, under the WTO's Plurilateral Agreement on Government Procurement (GPA), ${ }^{17}$ and regional regimes, such as the EU's procurement directives. ${ }^{18}$

Albeit committed to facilitating the allocation of public contracts based on best value within an open market, such systems allow government buyers ('contracting authorities') a certain measure of discretion in deviating from decision-making based on price alone. The precise scope and parameters of such discretion are generally determined by a regime-specific balancing between the primary objectives of efficiency, non-discrimination and free competition, on one hand, and contracting authorities' other needs and interests, including horizontal goals, on the other. For instance, the WTO's GPA system allows for certain public interest exceptions, ${ }^{19}$ even if its primary purpose is to liberalise public procurement as an area of international trade by applying the principle of non-discrimination in the conduct of the procurement activities covered by the Agreement. ${ }^{20}$ The European Union (EU) procurement

and Labour Rights: Towards Coherence in International Instruments of Procurement Regulation (Hart 2017), 46.

16 On potential exposure of public buyers to liability based on tort, see Vibe Ulfbeck, 'Supply Chain Liability of the Public Buyer' (2017) 3 European Procurement and Public-Private Partnership Law Journal, 325.

17 Revised Agreement on Government Procurement, March 2012, entered into force on 6 April 2014.

18 The European procurement framework comprises a number of directives: Directive 2014/24 on Public Procurement and Repealing Directive 2004/18 (EU Procurement Directive) [2014] OJ L 94; Directive 2014/25 on Procurement by Entities Operating in the Water, Energy, Transport and Postal Services Sector and repealing Directive 2004/17/EC (Utilities Directive) [2014] OJ L 94; Directive 2009/81/EC on Defence and Security Procurement OJ L 216/76 and Directives 89/665/EEC and 92/13/ EEC on Remedies (both amended by Directive 2007/66/EC, OJ L 335/31).

19 See Opi Outhwaite's chapter in this volume and Corvaglia, 'The Admissibility of the Inclusion of Social and Labour Rights Under the WTO Procurement Regulatory Framework' in Public Procurement and Labour Rights (n15).

20 Maria Anna Corvaglia, 'RegioPost and Labour Rights Conditionality: Comparing the EU Procurement Regime with the WTO Government Procurement Agreement' in Albert Sanchez-Graells (ed.), Smart Public Procurement and Labour Standards: Pushing the Discussion after RegioPost (Hart 2018), 246. 
regime, in turn, explicitly links the award of public contracts to compliance with the principles of free movement of goods, freedom of establishment and the freedom to provide services, as well as principles deriving therefrom, such as equal treatment, non-discrimination, mutual recognition, proportionality and transparency and for public contracts above a certain value, the principle of open competition. ${ }^{21}$ Yet sporadic steps were taken, over the years, by the Court of Justice of the European Union ${ }^{22}$ and European Commission, to accommodate social and environmental goals as legitimate horizontal objectives. ${ }^{23}$ More recently, the 2014 EU Procurement Directives established specific mechanisms, such as permission for buyers, on certain conditions, to exclude 'abnormally low tenders', and to require suppliers to obtain certifications based on compliance with environmental or labour criteria, intended to allow public buyers to meet non-competition objectives. ${ }^{24}$

Besides, it can be acknowledged, many procurement frameworks today are transitioning to the pursuit of value for money on a 'lifetime' basis. ${ }^{25}$ Accordingly, the highest available quality and the best price under the broadest possible competition no longer means just buying the cheapest possible supplies or services. ${ }^{26}$

Nonetheless, market-based ordering and the protection of economic operators from unfair discrimination during the purchasing process remain paramount goals in public procurement law frameworks. ${ }^{27}$ Measures to advance human rights, to the extent they entail deviations from these norms, are still

21 EU Procurement Directive, Recital 1.

22 Roberto Caranta, 'Sustainable Procurement in the EU', in Roberto Caranta and Martin Trybus, The Law of Green and Social Procurement in Europe (DJØF Publishing 2010); Olivier De Schutter, 'Public Procurement: The Power of the Purse' in Oliver De Schutter, Trade in the Service of Sustainable Development. Linking Trade to Labour Rights and Environmental Standards (Hart 2015).

23 European Commission, Buying Green! A Handbook on Environmental Public Procurement (2004, 2011 and 2016) http://ec.europa.eu/environment/gpp/buying handbook_en.htm; European Commission, Buying Social. A Guide to Taking Account of Social Considerations in Public Procurement (2011) http://ec.europa.eu/social/main .jsp?langId=en\&catId=89\&newsId $=978$.

24 Opi Outhwaite and Olga Martin-Ortega, 'Human Rights in Global Supply Chains: Corporate Social Responsibility and Public Procurement in the European Union' (2016) 10(1) Human Rights and International Legal Discourse, 41-71. See further Albert Sanchez-Graells (ed.), Smart Public Procurement and Labour Rights (n20); Corvaglia (n15).

${ }_{25}$ Marta Andrecka and Katerina Mitkidis, 'Sustainability Requirements in EU Public and Private Procurement - A Right or an Obligation? (2017) 1 NJCL 57.

26 Ibid, 63.

27 See e.g. Albert Sanchez-Graells, Public Procurement and the EU Competition Rules, 2nd edn (Hart 2015). 
generally subject to stringent requirements for justification. ${ }^{28}$ In practice, such an approach tends to narrow public bodies' ability to advance 'non-economic' goals such as protection of basic labour rights for supply chain workers through their purchasing decisions. ${ }^{29}$ Meaningful opportunities to select, or exclude, tenderers based on the extent to which their products or services can be said to respect human rights are often thus curtailed.

Meanwhile, strands of scholarly opinion at times appear to remain committed to a vision of competition whereby this is more compromised, than advanced, by the use of government spending power to eliminate exploitative practices from the marketplace. ${ }^{30}$ If other commentators and innovations in government buying practice, some illustrated by contributions to this book, have begun to question this paradigm, ${ }^{31}$ such an approach is likewise challenged by recent trends towards the application of human rights norms to the sphere of business activity and, last but not least, by increasing public concern at the persistence of serious human rights abuses linked to government supply chains.

\section{THE STATE AS BUYER: A HUMAN RIGHTS LENS}

States have international and domestic obligations to respect, protect and promote human rights. As already mentioned, the state duty to protect human rights extends to protecting rights-holders within the state's jurisdiction from harmful actions by third parties, whether natural or legal persons, the latter category including corporations and so suppliers to government. ${ }^{32}$

28 Outhwaite and Martin-Ortega, 'Human Rights in Global Supply Chains' (n26); Olga Martin-Ortega and Claire Methven O'Brien, 'Advancing Respect for Labour Rights Globally through Public Procurement' (2017) 5(4) Politics and Governance, 69-79.

29 International Learning Lab on Public Procurement and Human Rights (Claire Methven O'Brien et al.), Public Procurement and Human Rights: A Survey of Twenty Jurisdictions (n4); Amy Ludlow, 'Social Procurement: Policy and Practice' (2016) 7(3) European Labour Law Journal, 479-97.

30 See, for example, Albert Sanchez-Graells, 'Public Procurement and Human Rights: A Sketch of the EU Legal Framework', Chapter 6 in this volume.

31 See e.g. Anja Wiesbrock and Beate Sjåfjell, 'Public Procurement's Potential for Sustainability' in Beate Sjåfjell and Anja Wiesbrock (eds), Sustainable Public Procurement under EU Law: New Perspectives on the State as a Stakeholder (Cambridge University Press 2016), 234; Ludlow, 'Social Procurement' (n29); Andrecka and Mitkidis, 'Sustainability Requirements in EU Public and Private Procurement' (n25).

32 Clapham, Human Rights in the Private Sphere (Oxford University Press 1996); Methven O'Brien, 'The Home State Duty to Regulate' (n6). See further, Claire Methven O'Brien, 'The State Duty to Protect Against Business-related Human Rights 
The Universal Declaration of Human Rights (UDHR), together with the International Covenant on Civil and Political Rights (ICCPR) and the International Covenant on Economic, Social and Cultural Rights (ICESCR) are usually considered to be international human rights law's foundational instruments and as such are often referred to as the 'International Bill of Human Rights'. The ICCPR and ICESCR, as well as thematic and regional human rights treaties, such as the European Convention on Human Rights, define the main contours of states' international human rights law duties. Besides, human rights include certain labour rights. The basic labour rights recognised by the International Labour Organization's (ILO) Declaration on Fundamental Principles and Rights at Work (1998) are referred to as 'Core Labour Standards'. These comprise freedom of association and the effective recognition of the right to collective bargaining; the elimination of all forms of forced or compulsory labour; the effective abolition of child labour; and the elimination of discrimination in respect of employment and occupation. ${ }^{33}$

Historically human rights were viewed as guaranteeing dignity and fundamental freedoms against public rather than private actors. Human rights laws recognised only states as subjects ${ }^{34}$ and generally did not impose direct obligations or liabilities on non-state actors such as businesses, with very few exceptions. ${ }^{35}$ Against the backdrop of globalisation, and governance 'gaps' ${ }^{36}$ accompanying an increase in production via transnational supply chains, reg-

Abuses' in Claire Methven O'Brien, Business and Human Rights. A Handbook for Legal Practitioners (Council of Europe 2019), 15-25.

33 Core Labour Standards are protected by the following ILO instruments: ILO Convention 87 on Freedom of Association and the Protection of the Right to Organise; ILO Convention 98 on the Right to Organise and Collective Bargaining; ILO Convention 29 on Forced Labour; ILO Convention 105 on the Abolition of Forced Labour; ILO Convention 138 on Minimum Age; ILO Convention 111 on Discrimination (Employment and Occupation); ILO Convention 100 on Equal Remuneration; ILO Convention 182 on Worst Forms of Child Labour. As distinct from Core Labour Standards, labour rights are understood in this book as referring to workers' rights as established in national and international law, while labour or working conditions refer to the factual conditions under which goods are produced. Cf. Sanchez-Graells, who refers to "“core" human rights guarantees', a sui generis terminology not explicitly defined but which it can be said is not synonymous with 'Core Labour Standards': Sanchez-Graells, 'Public Procurement and Human Rights' (n30).

34 Rosalyn Higgins, 'Responding to Individual Needs' (n5).

35 For instance, relating to the involvement of businesses or their personnel in genocide, war crimes and some crimes against humanity.

36 UN Human Rights Council, 'Protect, Respect and Remedy: A Framework for Business and Human Rights: Report of the Special Representative of the Secretary-General on the issue of human rights and transnational corporations and other business enterprises, John Ruggie,' UN Doc. A/HRC/8/5, 7 April 2008, 3 para. 3. 
ulatory competition and outsourcing, since the 1990s this state-centric focus has been increasingly challenged, however, with the role and responsibilities of non-state actors receiving fresh consideration. ${ }^{37}$

Subsequently, a global wave of initiatives has sought to promote 'responsible' or 'sustainable' global value chains, where human rights are respected and risks to human rights pre-emptively assessed and addressed, as a critical contribution to achieving sustainable development, inclusive global growth and decent work. ${ }^{38}$ Such initiatives strongly emphasise the need for 'responsible business conduct' in achieving these goals, that is, business conduct that contributes positively to 'economic, environmental and social progress with a view to achieving sustainable development' and avoiding adverse human rights impacts. ${ }^{39}$ Two landmarks in this context are the UNGPs and the 2030 Agenda for Sustainable Development and related SDGs.

The UNGPs have become a central axis in defining responsible business. They are based on recognition of the 'role of business enterprises as specialized organs of society performing specialized functions, required to comply with all applicable laws and to respect human rights' ${ }^{40}$ The UNGPs comprise a series of elements intended to regulate this role and the impact of corporate activity on human rights articulated via a tripartite scheme, the UN Framework on Business and Human Rights 'Protect, Respect and Remedy', ${ }^{41}$ under which states have a duty to protect human rights; businesses have the responsibility to respect human rights, to be fulfilled in particular by undertaking human rights due diligence with regard to their own activities and business relationships; and victims have a right to access an effective remedy for business-related human rights abuses.

The UNGPs address public procurement as one dimension of the state duty to protect human rights, the UN Framework's first 'pillar' (Protect), which encompasses interactions between states and businesses of a commercial nature. Under UNGP 1, 'States shall take appropriate steps to prevent, inves-

37 For example, Phillip Alston (ed.), Non-state Actors and Human Rights (Oxford University Press 2005); Andrew Clapham, Human Rights Obligations of Non-state Actors (Oxford University Press 2006).

38 Claire Methven O'Brien and Olga Martin-Ortega, 'Discretion, Divergence, Paradox: Public and Private Supply Chain Standards on Human Rights' in Sanja Bogojević, Xavier Groussot and Jörgen Hettne Discretion in EU Procurement Law (Hart 2019).

39 OECD, Responsible Business Conduct in Government Procurement Practices (OECD June 2017) http://mneguidelines.oecd.org/Responsible-business-conduct-in -government-procurement-practices.pdf.

40 UNGPs (n7), 1.

${ }^{41}$ UNHRC, Protect, Respect and Remedy: A Framework for Business and Human Rights, UN Doc. A/HRC/17.31 (7 April 2018). 
tigate, punish and redress [business-related human rights abuses] through effective policies, legislation, regulation and adjudication'. UNGP 5 further recalls that, where states privatise or 'contract out' public services, they retain their human rights obligations and must 'exercise adequate oversight' to ensure these are met, including by ensuring that contracts or enabling legislation communicate the state's expectation that service providers will respect the human rights of service users. ${ }^{42}$ As noted by UNGP 6 (Commentary), it also entails that states should promote awareness and respect for human rights by businesses in the context of public procurement. At the same time, UNGP 4 highlights that states may require state-owned or controlled enterprises to exercise human rights due diligence, implicitly encompassing their purchasing function. Finally, UNGP 8 calls for 'policy coherence' to be achieved by the alignment of goals and practices across governmental departments, agencies and institutions which, as demonstrated by contributions to this book and as we discuss further in our concluding chapter, remains to be achieved as regards the law, policy and practice of public procurement.

Pillar II (Respect) is developed by UNGPs 11 to 24, which outline elements of the 'corporate responsibility to respect human rights'. ${ }^{43}$ This responsibility entails that businesses, which de facto include suppliers to governments, should avoid infringing on human rights while addressing any adverse human rights impacts with which they are involved.

As UNGP 13 points out, a corporation may be implicated in such human rights impacts in three ways - the latter two clearly encompassing supply chain relationships: (i) by causing adverse human rights impacts through its own activities; (ii) contributing to such impacts through its own activities - either directly or through another entity; or (iii) by being directly linked to such impacts via its operations, products or services, for instance, through relationships with business partners or other entities in the value chain.

Each of these three modalities, according to the UNGPs, demands a different corporate response. Where a business causes an adverse impact, it should cease or change its own activities to prevent any further impact or recurrence. If the abuse cannot be prevented, an enterprise should engage actively in remediation directly or in cooperation with others. Where a business contributes to an impact, it should use its leverage to mitigate any remaining harmful effects towards human rights. If the business is merely indirectly linked to the impact,

42 See generally, Antenor Hallo de Wolf, Reconciling Privatisation with Human Rights (Intersentia 2012).

43 Claire Methven O'Brien and Sumi Dhanarajan, 'The corporate responsibility to respect human rights: a status review', (2016) 29(4) Accounting, Auditing \& Accountability Journal, 542-67. 
it should still use its leverage to encourage the offending entity to prevent its recurrence or at minimum mitigate it. ${ }^{44}$

The concept of leverage is thus an important one. It refers to the ability of a business '...to effect change in the wrongful practices of the party that is causing or contributing to the impact'. ${ }^{45}$ Such parties include suppliers. If a supplier is abusing human rights, according to the UNGPs, a purchaser should assess its leverage to influence it, with reference to a series of factors including its degree of direct control over the supplier; the terms of the purchase contract; the proportion of the total business it represents for the supplier; and its ability to incentivise the supplier to improve its human rights performance through measures relating to future business, reputational advantage and capacity building assistance, for example. Where, in the face of persisting abuses by a supplier, a buyer is unable to increase its leverage, it should consider ending the business relationship, particularly where abuses are severe. If this is not possible, because the relationship is crucial, or because terminating the relationship would itself have serious human rights consequences, a buyer should demonstrate a continuing effort to mitigate the adverse impacts and be prepared to accept the consequences of such relationship. ${ }^{46}$

The key to avoiding adverse impacts, according to the UNGPs, is 'human rights due diligence,' which shifts the traditional corporate due diligence process from the identification of risks to the business to the identification of risks to human rights that the business and its activities pose for others. ${ }^{47}$ A 'core requirement' of the corporate responsibility to respect human rights, this is a proactive process of identification, prevention and mitigation of risks to human rights adaptable to all businesses, irrespective of individual characteristics. ${ }^{48}$ After adopting and publishing a policy commitment to respect human rights, human rights due diligence comprises four steps: i) human rights risk and impact assessment; ii) integrating assessment findings into company policies and procedures; iii) monitoring the effectiveness of company responses to human rights impacts; iv) communicating and reporting on human rights impacts and due diligence. Besides, as a final element of due diligence's minimum requirements, where they cause or contribute to human

\footnotetext{
44 UNGPs 13, 19.

45 UNGP 19, Commentary, 21.

46 Ibid, 22, UN, The Corporate Responsibility to Respect Human Rights. An Interpretative Guide (2012), 18.

47 Olga Martin-Ortega, 'Human Rights Due Diligence for Corporations: From Voluntary Standards to Hard Law at Last?' (2014) 32 Netherlands Quarterly of Human Rights, 44-74.

48 UN Human Rights Council, Implementing the United Nations 'Protect, Respect and Remedy Framework' (n41), para. 6.
} 
rights abuses, businesses should provide for, or cooperate in, their remediation, via judicial or non-judicial mechanisms. ${ }^{49}$ Mirroring norms embodied in human right instruments, as already mentioned, the corporate responsibility to respect human rights applies across all jurisdictions. Accordingly, wherever they operate, businesses should not seek to exploit gaps in domestic laws or their enforcement, while they may also need to go further than required by applicable legislation. ${ }^{50}$

Thus, the UN Framework and UNGPs articulate the human rights responsibilities of businesses, whether they act as purchasers or suppliers, to other businesses or to government buyers. At the same time, the UN Framework and UNGPs point directly to the duty of the state to regulate its purchasing activity so as to align with and promote the realisation of this corporate standard. Moreover, the notion of 'responsible business conduct,' understood as business behaviour that avoids, mitigates and addresses adverse human rights impacts in value chains, so 'contributing positively to economic, environmental and social progress' ${ }^{51}$ has assumed a central role in a subsequent wave of international policy initiatives.

In 2011, the OECD aligned its Guidelines for Multinational Enterprises with the UNGPs. ${ }^{52}$ As described above, the UNGPs indicate that companies' responsibility to respect human rights extends beyond their own operations to the activities of business partners, including suppliers and sub-contractors, wherever located. This has, in addition, provided a basis for the development by the OECD of detailed supply chain management guidance by industry sector encompassing human rights, for instance, addressing banking and finance, footwear and apparel, in addition to precious metals. ${ }^{53}$ Besides, the OECD has recently issued comprehensive 'responsible business conduct' due diligence guidance, ${ }^{54}$ while multi-stakeholder initiatives, industry associations and governments have likewise produced guidance to support implementation of human rights due diligence on a sector-specific basis.

\footnotetext{
49 UNGPs 15, 17-20; UNGP 22, Commentary, 24

$50 \mathrm{UN}$, Interpretative Guide (n46), 77 and UNGP 23 (b).

51 OECD, Responsible business conduct in government procurement practices, available at: http://

mneguidelines.oecd.org/Responsible-business-conduct-in-government-procurement -practices.pdf.

52 OECD, Guidelines for Multinational Enterprises (2011, OECD), http:// mneguidelines.oecd.org/guidelines/.

${ }_{53}$ See further: http://www.oecd.org/investment/due-diligence-guidance-for -responsible-business-conduct.htm.

54 OECD, Due Diligence Guidance for Responsible Business Conduct (Paris: OECD, 2017).
} 
In the European context, the 'responsible management of global supply chains' has been identified as essential 'to align trade policy with European values'. ${ }^{55}$ It is also a key element of the European Commission's latest Corporate Social Responsibility Strategy. Under this, '[t]o identify, prevent and mitigate their possible adverse impacts, large enterprises, and enterprises at particular risk of having such impacts, are encouraged to carry out risk-based due diligence, including through their supply chains'. ${ }^{56}$ The Council of Europe, principal custodian of European human rights instruments, has also aligned itself with the UNGPs, their articulation of the state duty to protect human rights in the business context and the concept of human rights due diligence. ${ }^{57}$

Amongst international policy actors and the states behind them, there is evidence of an increasing concern to integrate respect for human rights, including but not limited to ILO Core Labour Standards, into global value chains and associated supply chain standards and practices. Inter alia this has triggered the development of binding obligations for public actors and corporations in the context of so-called conflict minerals, the timber trade and non-financial reporting. ${ }^{58}$ Responsible global value chains have, furthermore, become a central theme across EU policy instruments and mechanisms touching on sustainable development and the SDGs. ${ }^{59}$

55 European Commission, Trade for All: Towards a more responsible trade and investment policy (COM(2015) 0497), 4.2.3.

56 European Commission, Communication from the Commission to the European Parliament, the Council, the European Economic and Social Committee and the Committee of the Regions. A renewed EU strategy 2011-14 for Corporate Social Responsibility, $\operatorname{COM}(2011) 681$ final, 6.

57 Council of Europe Recommendation CM/Rec(2016) 3 of the Committee of Ministers to Member States on Human Rights and Business https://edoc.coe .int/en/fundamental-freedoms/7302-human-rights-and-business-recommendation -cmrec20163-of-the-committee-of-ministers-to-member-states.html.

58 See e.g. Regulation (EU) No. 2017/821 of the European Parliament and the Council of 17 May 2017, laying down supply chain due diligence obligations for Union importers of tin, tantalum and tungsten, their ores and gold originating from conflict-affected and high risks areas; Regulation (EU) No. 978/2012 of the European Parliament and of the Council of 20 October 2010 laying down the obligations of operators who place timber and timber products on the market; Directive 2014/95/EU of the European Parliament and of the Council of 22 October 2014 amending Directive 2013/34/EU as regards disclosure of non-financial and diversity information by certain large undertaking and groups, respectively. Regarding the application of the UK Modern Slavery Act to public bodies see Olga Martin-Ortega, 'Human Rights Risks in Global Supply Chains: Applying the UK Modern Slavery Act to the Public Sector', Global Policy (2017) 8, 2017, 512-21.

59 See e.g. European Commission, Communication from the Commission to the European Parliament, the Council, the European Economic and Social Committee and the Committee of the Regions, Next steps for a sustainable European future. European 
Supplementing international and regional initiatives, and in furtherance of the 'state duty to protect human rights' highlighted by Pillar I of the UN Framework, a growing number of national governments have adopted standards embodying duties for companies to undertake human rights due diligence. Recent legislation in the United States, United Kingdom and France requires companies to disclose information on their supply chains and their efforts to perform human rights due diligence. ${ }^{60}$ Besides, twenty-one EU governments so far have adopted National Action Plans on Business and Human Rights, of which twenty address public procurement explicitly, ${ }^{61}$ while such NAPs are a growing phenomenon also in the Americas and Asia. ${ }^{62}$ Amongst similar progressions at international level, the ISO's recently issued Sustainable Procurement Guidance also aligns itself with the UNGPs. ${ }^{63}$ A consolidation of expectations on both the state and its suppliers to ensure human rights are respected in the context of government purchasing relationships and the production and service delivery processes subordinate to it can thus clearly be discerned.

Turning to the 2030 Agenda for Sustainable Development, this aims to provide a comprehensive and universal platform encompassing the environmental, social and economic dimensions of sustainable development. ${ }^{64}$ The SDGs accordingly define objectives spanning poverty, hunger, health, education, global warming, gender equality, water, sanitation, energy, urbanisation and environment and decent work. The 2030 Agenda and SDGs reflect the role of governments as 'megaconsumers', with purchasing power that can shift markets towards sustainable production. ${ }^{65} \mathrm{UN}$ Sustainable Development Goal 12 sets new objectives on public procurement as part of the drive towards sustainable production and consumption and more inclusive economies. Each

action for sustainability, 22 November 2016, COM(2016) 739 final; Regulation (EU) 2017/1601 of the European Parliament and of the Council of 26 September 2017 establishing the European Fund for Sustainable Development (EFSD), the EFSD Guarantee and the EFSD Guarantee Fund, OJ 27 September 2017.

60 Loi no. 2017-399 du 27 Mars 2017 relative au devoir de vigilance des sociétés mères et des entreprises donneuses d'ordre, https://www.legifrance.gouv.fr/ affichTexte.do?cidTexte=JORFTEXT000034290626\&categorieLien=id; UK Modern Slavery Act 2015, http://www.legislation.gov.uk/ukpga/2015/30/contents/enacted; California Transparency in Supply Chains Act 2010, https://oag.ca.gov/SB657.

${ }_{61}$ Danish Institute for Human Rights (DIHR), National Action Plans on Business and Human Rights, Public Procurement: https://globalnaps.org/issue/public -procurement/.

${ }_{62}$ DIHR, National Action Plans on Business and Human Rights: https://globalnaps .org/.

63 ISO 20400 Sustainable Procurement - Guidance ISO 20400:2017(E) 1st Edition.

64 UNGA (n9).

65 Ibid. 
SDG is articulated through a series of more specific targets. Under SDG 12, Target 12.6 is to encourage businesses, especially large and transnational companies, to adopt sustainable practices and to integrate sustainability information into the reporting cycle; and Target 12.7 is to promote public procurement practices that are sustainable, in accordance with national policies and priorities. ${ }^{66}$ All countries are thus called on to implement sustainable public procurement policies and action plans.

To sum up, the SDGs reinforce, at the level of international policy, budding international recognition of the role and significance of public purchasing in the context of sustainable, human rights-based development; ${ }^{67}$ the UNGPs counsel policy coherence and the integration of human rights into national and supranational public procurement frameworks, as well as advancing specific expectations regarding the management of supply chain human rights risks, in the form of human rights due diligence, that bears clear relevance to both private and public buyers. Finally, to reiterate, such developments are entirely consistent, from a human rights point of view, with the fact that the state and its contracting authorities have not only a discretionary capacity to protect human rights through public procurement, but a legally based duty to do so. A recent and logical development, given this, with its Modern Slavery Act 2018 Australia became the first country to establish legal obligations for government entities to report annually on human rights risks 'in their operations and supply chains, and actions to address those risks' ${ }^{68}$

\section{SUSTAINABLE PUBLIC PROCUREMENT: ANALYSING THE HUMAN RIGHTS DIMENSION}

As foreseen in Section 2, procurement law's approach to horizontal objectives continues to evolve. In many jurisdictions, the concept of 'sustainable public procurement' embodies its latest iteration. ${ }^{69}$ This has been defined as 'a process

${ }^{66}$ UN Sustainable Development Platform, Sustainable Development Goal 12 https://sustainabledevelopment.un.org/sdg12.

${ }_{67}$ Claire Methven O'Brien and Olga Martin-Ortega 'The SDGs, Human Rights and Public Procurement: An Urgent Need for Policy Coherence' in United Nations Office for Project Services (ed.), High Impact Procurement. Supporting Sustainable Development (UNOPS 2017) https://content.unops.org/publications/ASR/ASR -supplement-2016_EN.pdf?mtime=20171214185155.

${ }_{68}$ Parliament of the Commonwealth of Australia, Modern Slavery Bill 2018 https://parlinfo.aph.gov.au/parlInfo/download/legislation/bills/r6148_aspassed/toc _pdf/18134b01.pdf;fileType=application/pdf, sections 3-5.

69 Anastasia O'Rourke, Charlotte Leire and Trevor Bowden, Sustainable Public Procurement: A Global Review (2013, United Nations Environment Programme); Caranta, 'Sustainable Procurement in the EU' (n22), 17. 
where organisations meet their needs in a way that achieves value for money on a lifetime basis and allows delivery of aspects beyond savings, such as environmental and social objectives' ${ }^{70}$ Hence some procurement scholars highlight the need to transcend any perception of strict hierarchy between 'primary' and other procurement objectives, in favour of a more reflective calibration between these. Sjåfjell and Wiesbrock thus define sustainable procurement as entailing a '...balancing and not of choosing either economic efficiency or environmental protection and social development'. ${ }^{71}$

Whereas we agree that a balancing act between the competing policy and institutional aims embodied by any procurement process is inevitable in practice, we would nevertheless maintain that human rights law in principle demands a different analysis. Specifically, we suggest, public buyers' duties, arising under international, regional and national human rights instruments, and applied to the sphere of business regulation, render the protection of human rights distinct from other 'social' or sustainable procurement objectives of a discretionary nature.

Generally, this distinct character of human rights as a dimension of sustainable procurement is not acknowledged by procurement law, or by published policies and guidance on social or 'sustainable' procurement. For example, the European Commission's Buying Social Guide describes socially responsible public procurement as procurement that takes into account one or more of the following social considerations: promoting 'employment opportunities, decent work, compliance with social and labour rights, social inclusion (including persons with disabilities), equal opportunities, accessibility design for all, taking account of sustainability criteria, including ethical trade issues ... and wider voluntary compliance with corporate social responsibility (CSR), while observing the principles enshrined in the Treaty for the European Union (TFEU) and the Procurement Directives'. ${ }^{72}$ Human rights are later mentioned

70 Marta Andrecka, 'Corporate Social Responsibility and Sustainability in Danish Public Procurement', European Procurement and Public-Private Partnership Law Review, 3/2017, 333.

${ }^{71}$ Beate Sjåfjell and Anja Wiesbrock, 'Why should public procurement be about sustainability?' in Sjåfjell and Wiesbrock (eds) Sustainable Public Procurement under $E U$ Law (n33) 4. The authors argue that human rights are included in their definition of sustainable procurement.

72 European Commission, Buying Social (n23), 5. At time of writing, the European Commission is developing new 'social procurement' guidance. In that context the current authors have advocated the establishment of human rights as an explicit dimension of a revised definition of socially responsible procurement: Claire Methven O'Brien and Olga Martin-Ortega, Guidance on Socially Responsible Public Procurement: Response to Consultation of the European Commission by the International Learning Lab on Procurement and Human Rights http://www.hrprocurementlab.org/blog/articles/ 
in the Buying Social Guide as one of 'the social considerations' which 'could be relevant for procurement', without reference to the human rights duties of public buyers under EU or national laws, nor guidance on how they should be integrated in the interpretation and application of the EU procurement regime. $^{73}$

Hence, this book, along with a small but growing body of contributions by ourselves and others, ${ }^{74}$ begins to advance the needed legal analysis of the scope and content of states' obligations to protect human rights in the government buying context, as well as the viability of implementing this duty in practice. Undoubtedly, further work is needed in both respects. Meanwhile, however, as this volume equally demonstrates, the human costs of current approaches to social and sustainable procurement that mistakenly assimilate human rights to the broader category of horizontal or secondary objectives, denying them their proper regulatory role and effect in guiding state decisions and business actions, is an unacceptable one.

A re-engineering of public procurement rules in some significant respects, founded on widespread acceptance of a new concept and legal definition of socially responsible public procurement that afford human rights their proper role and status, is thus urgently required. ${ }^{75}$ By highlighting the contours, shortcomings and opportunities presented by current procurement law and policy frameworks, and documenting compelling case studies of public buyers' successes and failures in fulfilling their duty to protect in the context of their purchasing activities, this book aims to hasten progress towards this goal.

\section{$5 \quad$ ABOUT THIS BOOK}

The remainder of this volume is divided into three parts.

guidance-on-socially-responsible-public-procurement-response-to-consultation-of-the -european-commission-by-the-international-learning-lab-on-procurement-and-human -rights/.

73 The Guide merely refers to 'protecting against human rights abuse and encouraging respect for human rights', European Commission (n23), 9.

74 Claire Methven O'Brien, 'Essential Services, Public Procurement and Human Rights in Europe', University of Groningen Faculty of Law Research Paper No. 22/2015 https://papers.ssrn.com/sol3/papers.cfm?abstract_id=2591898; Methven O'Brien, Business and Human Rights. A Handbook for Legal Practitioners (n40) 32-48; Martin-Ortega, 'Human Rights Risks in Global Supply Chains (n69); Deborah Russo, 'The Duty to Protect in Public Procurement: Towards a Mandatory Human Rights Clause? in Angelica Bonfanti (ed.), Business and Human Rights in Europe. International Law Challenges (Routledge, 2018), 59-70.

75 Methven O'Brien and Martin-Ortega, Chapter 14 in this volume. 
'Part II: Frameworks and Actors' brings together contributions from scholars and legal practitioners that explore the interface between procurement rules and human rights in specific legal and institutional settings. In doing so, it identifies and reflects on several important transversal issues.

Opi Outhwaite's chapter navigates the normative framework of the WTO, analysing both restrictions on and scope for the respect and integration of human rights by national procurement rules within the parameters defined by the Government Procurement Agreement. Sope Williams-Elegbe's chapter explores the constellation of norms and rules applicable to procurements under the auspices of the World Bank, with a particular focus on Bank-funded procurements, as a primary mechanism in the facilitation of loans to developing countries. She also assays the implications of the UNGPs in the World Bank context. Next, Deborah Russo's chapter considers procurement by international organisations (IOs) and how this should be analysed from the point of view of public international law and human rights law respectively. A case study based on the procurement practice of the UN International Children's Emergency Fund (UNICEF) illustrates some of the elements that IOs may adopt in attempting to prevent and address supply chain human rights abuses.

Geo Quinot's chapter centres on South Africa's procurement framework. On South Africa's transition from apartheid to democracy, public procurement was seen as an important tool for redressing historical and continuing racial inequalities. The chapter's review of the strengths and limitations of the framework initially applied and its subsequent iterations is ground-breaking in uncovering the potential strengths and limitations of procurement as a tool for advancing human rights, equality and social justice, based on hard experience. Albert Sanchez-Graells works within the context of the EU's legal and policy framework on public procurement and delivers a sceptical view of the scope, in practice, for the new mechanisms notionally provided by the 2014 EU Procurement Directives to advance 'social' concerns. By contrast, Eamonn Conlon's chapter more optimistically prospects new legal avenues, triggered by the same Directives, for the pursuit of redress by workers in European public supply chains where International Labour Organization (ILO) Core Labour Standards are not observed, with particular reference to Ireland implementing legislation and civil damages laws. Finally, Axel Marx's chapter provides a study of voluntary social standards. Weighing evidence relating to the effectiveness of such standards as supply chain governance instruments from the environmental context, he evaluates the possible utility of 'social labels' in addressing human rights abuses in the procurement context.

'Part III: Opportunities and Challenges: Insights from Practice' assembles studies of public purchasing generated by professionals working at the 'front line' of public procurement practice across world regions. Its contributions 
hence constitute valuable 'raw data' that can both inform and challenge the analyses and reflections in Parts II and III.

James Sinclair's chapter concerns bonded labour in the context of military and diplomatic outsourcing, including during the Iraq and Afghanistan conflicts, and the egregious risks to security workers and those they are intended to protect posed by lack of effective oversight of security contractors in government funded supply chains. Pauline Göthberg explains, in her chapter, how human rights have been integrated into the terms and practice of public procurement by Sweden's county councils, describing their experience of developing a collaborative model for purchasing of healthcare supplies. Importantly, her contribution demonstrates the practicability of introducing human rights considerations into government buying procedures; that such measures may be effective in improving conditions for supply chain workers; and the value that public buyers may derive from the adoption of collaborative approaches in this area. Caroline Emberson and Alexander Trautrims, through their study of modern slavery and associated exploitation linked to procurement in the English adult social care system, likewise demonstrate that there are real risks to workers, and service users, if public procurement decisions fail to integrate human rights safeguards. Thus the chapter raises challenging questions about the human rights consequences of the marketisation of publicly funded social care provision. In the setting of the electronics industry, Björn Claeson's contribution provides evidence of the weaknesses of private supply chain governance systems in safeguarding workers' rights. Given this, he suggests, public buyers should, and can, make rights effective for workers in their supply chains via enforceable human rights contract clauses; meaningful worker involvement in monitoring; and steps to address systemic barriers to remediation of human rights abuses which are inherent in global trading conditions. Lastly, Robert Stumberg and Nicole Vander Meulen focus on supply chain transparency in the context of apparel procurement. Their chapter documents several examples of public buyers applying transparency requirements to advance respect for human rights in their supply chains, including the Madison, Wisconsin, 'sweatfree' policy and its cooperative contract for uniforms. Such examples, they argue, make the case for widening legislative authority for public buyers to incorporate human rights standards in tenders and for limiting commercial privacy as a constrain on such initiatives. Public buyers, they furthermore conclude, may maximise their leverage, visibility and economies of scale by collaborating in consortia.

Finally, drawing on the foregoing analyses, in Part IV we present our conclusions. In Chapter 14, we firstly identify the principal opportunities, risks and dilemmas highlighted by the various contributions to this volume. A clear reckoning of these, we suggest, must be a crucial preliminary to further progress towards fulfilling states' duties to protect human rights in 
the market sphere and in leveraging procurement to realise the 2030 Agenda and Sustainable Development Goals. To this end, we conclude the book by describing the main elements of a revised concept of sustainable procurement, whereby human rights are clearly acknowledged as a discrete and mandatory dimension. 